\title{
Fresh Water-an Emerging Global Concern with Special Reference to India
}

\author{
Akshey Bhargava ${ }^{1 *}$, Swati Bhargava ${ }^{2}$, Nirali Chandera ${ }^{3}$ and Unnati Patel ${ }^{4}$ \\ ${ }^{1}$ Department of Civil Engineering, Global Institute of Engineering and Technology, India
}

${ }^{2}$ Masters in Sustainable Environmental Design, AA School of Architecture, UK

${ }^{3}$ Department of Envirovision, India

${ }^{4}$ University of Windsor Ontario, Canada

Received: 阱June 15, 2018; Published: 阱June 27, 2018

*Corresponding author: Akshey Bhargava, Department of Civil Engineering, Global Institute of Engineering and Technology, India

\begin{abstract}
Increase in population requires increased demand of fresh water with the life style of people. Fresh water is a limiting resource and consequently there has been an increasing water stress in many parts of the world. Such a stress is assuming alarming proposition leading to conflicts and fights and may further aggravate the situation to an alarming level. An effort has therefore been made by the authors of the present paper to assess and present the situation at global and India level for evaluating and formulating the timely actions.
\end{abstract}

Keywords: Water; Global availability; Demand; Population; Water stress

\section{Introduction}

The world population was 2.5 billion in 1950, 4.4 billion in 1980, 6 billion in 2000 and projected to grow to 8 billion in 2025 and further likely to increase to 9.3 billion in 2050. Majority of this growth will occur in urban areas of developing countries (UNDESA, 2002). Such an increase in population coupled with higher standards of living will pose enormous strains on land, water, energy, and other natural resources. In the present context, the growing population and resulting demand for water is one of the most significant global concerns facing the mankind currently and in future. The availability and quality of freshwater resources around the world are of growing concern along with growing climate change which has resulted into misbalancing water resources [1].

Understanding the problem of freshwater scarcity begins by considering the distribution of water on the planet. Approximately $98 \%$ of our water is salty and only $2 \%$ is fresh. Of that $2 \%$, almost $70 \%$ is snow and ice, $30 \%$ is groundwater, less than $0.5 \%$ is surface water (lakes, rivers, etc) and less than $0.05 \%$ is in the atmosphere. Climate change has several effects on these proportions on a global scale. The main one is that warming causes polar ice to melt into the sea, which turns fresh water into sea water, although this has a little direct effect on water supply

\section{Global Water Budget}

It is estimated that the world contains about 1.4 billion $(1,386$ million) $\mathrm{km}^{3}$ of water (Shiklomanov, 1998) which is enough to cover the entire globe with a layer of water $2,718 \mathrm{~m}$ deep (Shiklomanov, 1993). It is aptly said that water is difficult to create or destroy under most natural conditions and thus it recycles globally through its three states of liquid, solid, and vapor [2]. As a result, the total quantity of water on Earth today has remained relatively constant since approximately 2 billion years ago (Christopherson, 2002). Out of the total water available on earth, $2.5 \%$, amounting to about 35 million $(35,029,000) \mathrm{km}^{3}$ is freshwater and if all this water was located on the surface and evenly distributed, it would be enough to cover all the continents with a layer of water $235 \mathrm{~m}$ deep (Shiklomanov, 1993). However, approximately two-thirds of this freshwater $\left(24,364,000 \mathrm{~km}^{3}\right)$ occur in the form of permanent ice or snow in polar and mountainous regions and is not readily accessible for use [3]. Hence, liquid freshwater (including atmospheric vapor 
and biological water) available is only $10,665,000 \mathrm{~km}^{3}$, or $0.77 \%$ of the global water resource [4].

The most of the fresh water is available as ground water which is to the tune of $10,530,000 \mathrm{~km}^{3}$ or $98.7 \%$ whereas less than 1 percent of the order of $104,620 \mathrm{~km}^{3}$ occurs in lakes, marshes and wetlands, and rivers, and only $0.1 \%$ amounting to $12,900 \mathrm{~km}^{3}$ is in the atmosphere as water vapor. However, useable freshwater comes from rainfall which is generated through the hydrologic cycle and this water is recycled continuously as a result of evaporation driven by solar energy [5]. The water evaporates from the oceans is of the order of $502,800 \mathrm{~km}^{3} / \mathrm{yr}$ which falls on the earth as precipitation to the tune of $458,000 \mathrm{~km}^{3} / \mathrm{yr}$ resulting in continuous transfer of freshwater from the ocean to the land. However, the average annual rainfall over land accounts to $119,000 \mathrm{~km}^{3} / \mathrm{yr}$ which is only $20 \%$ of all precipitation over the Earth out of which around $74,200 \mathrm{~km}^{3} / \mathrm{yr}$ evaporate back into the atmosphere (Shiklomanov, 1998). It may however be noted that countries are defined 'water stressed' when annual water supplies drop below $1,700 \mathrm{~m}^{3} /$ person whereas 'water scarce' when drop below $1,000 \mathrm{~m}^{3}$ /person. A country is defined as high water stress if demand is greater than 40 percent of the renewable water supply [5].

\section{Indian Scenario}

India has 16 percent of the world's population whereas only 2.5 percent of the worlds land area and 4 percent of the world's water resources at its disposal. Around 4,000 trillion liters of fresh water is provided through precipitation in the form of rain and snowfall in India out of which majority is returned to the oceans via rivers and a portion of this water is absorbed by the soil which is stored in underground aquifers whereas smaller percentage is stored in inland water bodies such as lakes, ponds, tanks and reservoirs [6]. It has been estimated that around 1,869 trillion liters of water reserves are available in India out of which only an estimated 1,122 trillion liters can be exploited due to topographic constraints and distribution effects [7]. However, the demand for water has been increasing at a high pace in the past few decades and the current consumption in the country is approximately 581 trillion liters with irrigation requirement as high as 89 percent followed by domestic use at 7 percent and industrial use at 4 percent [8].

The rapid increase in population, urbanization and industrialization has resulted into significant increase in water requirement in as much as that industrial requirement is expected to be doubled from existing 23.2 trillion liters to 47 trillion liters in next decade whereas domestic demand is expected to grow by 40 percent from 41 to 55 trillion liters while irrigation will require only 14 percent amounting to 592 trillion liters from existing 517 trillion liters. It has also been estimated that demand in the country will very soon overtake the availability of water. However, in some regions of the country, it has already happened. As per the Ministry of Water Resources, Government of India the per capita water availability in 2025 and 2050 is estimated to come down by almost 36 percent and 60 percent respectively as compared to 2001 levels.

India has turned into water deficiency country and over the coming years the demand scenario is projected to become worse in as much as that water supply for the average citizen could drop from an average of 105 liters to only 65 liters a day with a large section of the population having no access to potable water. There has been a regional disparity in availability of water across the country due to uneven rainfall and most of Indian cities, including Chennai and Mumbai, depend on rainfall for their yearly water supply. Moreover, groundwater levels have reduced significantly for the last 60 years and as a result out of total 5723 blocks assessed across India by the Central Ground Water Authority, 839 have been found to be overexploited, and 226 are classified as critical, while 550 are under the semi critical stage.

\section{Conclusion}

Fresh water availability is essential for the survival of human kind and supporting attributes but with the growing population with increasing life style, the needed fresh water demand is posing threat to the available resources. In Indian context, the most of fresh water occur on account of rain fall but majority of which is discharged in oceans through rivers. Therefore, there is a strong need with commitment to interlink all the Indian rivers so that fresh water is not allowed to be wasted by entering into oceans. If such an arrangement is made, the availability of fresh water will be distributed across the country to avoid regional disparity.

\section{References}

1. Bergkamp G, Orlando B, Burton I (2003) Change. Adaptation of water management to climate change. IUCN-The World Conservation Union, Gland, Switzerland and Cambridge, pp. 53.

2. Chistopherson RW (2002) Geosystems: an introduction to physical geography ( $4^{\text {th }}$ edn.). Prentice Hall, Upper Saddle River, New Jersey, pp. 626. plus appendices. In: Clarke R (1991) Water: the international crisis: Earthscan Publ. Ltd, London, UK, pp. 193.

3. Connor R (1999) North America's freshwater resources: emerging trends and issues: Comm. Environmental Cooperation, Montreal, Canada, pp. 30.

4. Dinar A, Rosegrant MW, Meinzer Dick R (1997) Water allocation mechanisms-principles and examples. Policy Research Working Paper no. WPS 1779, the World Bank Group, pp. 40.

5. Samuel TL, Larsen (2009) Lack of Freshwater Throughout the World.

6. Chennai Water Desalination Limited.

7. Central Ground Water Authority.

8. International Water Management Institute (IWMI). 


\section{(c) (i) This work is licensed under Creative Commons Attribution 4.0 License}

To Submit Your Article Click Here: $\quad$ Submit Article

DOI: 10.32474/CIACR.2018.03.000162

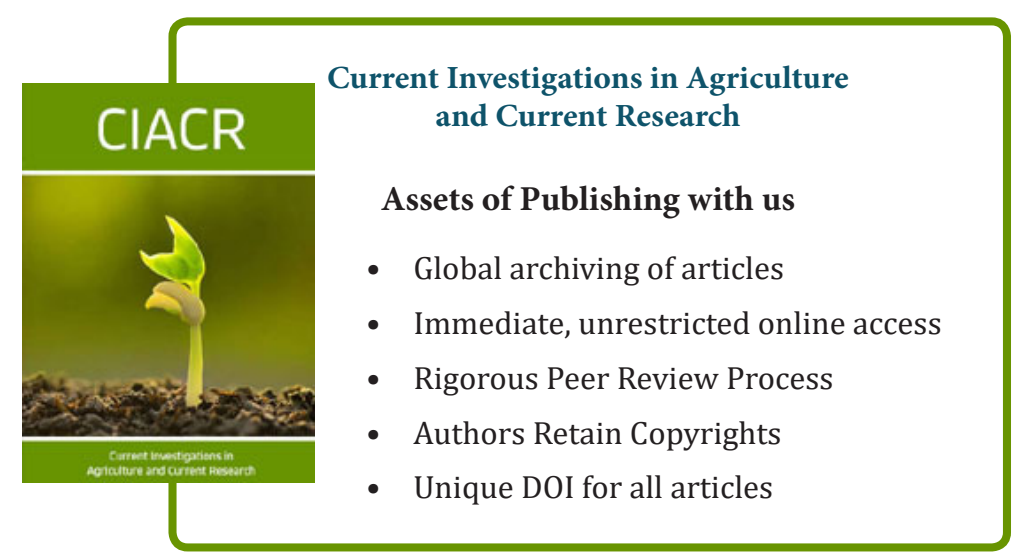

